\title{
Technical Setbacks Encountered in Internet Based Travel Booking Applications
}

\author{
Sumathy Arjunan, S. Barani Chelvi, B. Venkata Srilatha
}

\begin{abstract}
This study aims at identifying the factors which influence the customers to use cab apps. Due to the continuous growth and usage of internet and smart phones the service industry has widened their services through online mobile apps. Some major factors are identified through this study and anova and chi-square are used for data analysis. It is found from the study that consumers are mostly influenced by advanced booking technology and view on multiple devices. (Key words: convenience, advanced booking, cab apps, view on multiple devices).
\end{abstract}

Keywords: smart phones, data analysis

\section{INTRODUCTION}

In recent years, technology is increasing in a vast manner. This increase has lead to the growth of our economy in various fields. This vast growth has a major impact on the three sectors of our economy namely, agriculture, industry, service sectors. Service sector includes arts and entertainment services, information services, tourism and travel services, health care services and recreation services. In recent years, transportation facilities have undergone a tremendous change. There is a wide range of choices available for transportation for the customers. Among the various choices, cab facility has become one of the most important choice for the people in the metropolitan and urban areas. The growth of car rental industry is growing with the support of technology. Nowadays customers are using several mobile apps to book cabs at any time and from any place in urban areas. The pricing strategy used by the cab apps is also positively influencing the customers. When compared to the autos and buses in metropolitan cities. Many car rental industries has transformed with the help of internet technology so the customers are able to easily access through their mobile phones at flexible prices because of the tough competition among organized cab operators. In this regard the present paper briefs about the behavior of consumers while booking cabs.. Upadhyaya had explained how Meri Cab Company had collected feedback from its customers and enhanced its service quality for sustaining in the business.

Revised Manuscript Received on December 30, 2019.

Sumathy Arjunan, Assistant Professor, Department of Science \& Humanities,Bharath Institution Of Higher Education And Research TamilNadu,India.Email: sumi.renu@gmail.com

S. Barani Chelvi, Assistant Professor, Department of Science \& Humanities,Bharath Institution Of Higher Education And Research Email: baranikarthi1629@gmail.com

Venkata Srilatha Assistant Professor, Department of Science \& Humanities,Bharath Institution Of Higher Education And Research bvsrilatha27@gmail.com

\section{OBJECTIVES}

1. To know about the most preferred cab apps.

2. To study the factors which influence to use cab apps

\section{HYPOTHESIS:-}

1.H0- There is no significant relationship between income and the factors which influence to use cab apps.

H1- There is significant relationship between income and the factors which influence to use cab apps.

\section{REVIEW OF LITERATURE}

1. D. Shanthi International Journal of Intellectual Advancements and Research in Engineering Computations The motivation behind this paper is to examine the elements impacting the purchasers while choosing taxi administrations. The reliant variable is 'coupon reclamation conduct' and autonomous factors are inventiveness and value cognizance. The connection among reliant and autonomous factors are observationally checked through factual strategies. The factual apparatuses like connection, relapse and graphic insights are utilized for information investigation. It is found from the examination that customers are intrigued to recover coupons while choosing taxi administrations. It is additionally uncovered from the examination that customers are agreeable to reclaim coupons through versatile applications while booking taxi administrations. [1]-[4]

2. Adewole Adewumi Transportation is an issue of worry in huge urban areas of many creating nations today. Because of the enormous populace in these urban areas, there is consistent traffic clog and contamination. Thus taxi administrations are normal. In Nigeria, organizations offering these administrations have found that they can all the more likely serve the enormous populace by giving their administrations through the portable stage. Given the wide spread selection of advanced cells in these areas, we planned, created and sent an Android-based application for one of the taxi administration organization flagged down Red Cab. [5]-[10]

3. Mohammed Imranesh October 2017 The long haul advancement of a portable booking taxi application administration relies upon the proceeded with utilization of its travelers. The point of this examination is to explore the determinants of the versatile taxi booking application administration's duration aim, utilizing the innovation continuation hypothesis by including the apparent hazard and abstract standards.

The information were gathered by looking over 387 clients of 
the versatile taxi application administration. The information were investigated by applying the fractional least squares strategy. The examination indicated that the innovation duration hypothesis has broad capacity to disclose the continuation expectation to utilize the versatile booking taxi application. Emotional standards likewise significantly affect the frame of mind of portable booking taxi application clients which speaks to a significant commitment to innovation duration hypothesis augmentation.

Confinements :- The examination has certain hindrance of which a couple are recorded underneath:

1.The results and disclosures are kept to a limited domain.

2.The evaluations of the respondents may be uneven.

3.Time and resource basic. [16]-18]

\section{RESEARCH METHODOLOGY}

1.Research setup is the ordered plan of coordinating an assessment study. Undeniable explore arrangement has been used in the assessment.

2.Descriptive examination attempts to explain purposely an example, and gives data concerning dispositions and tendencies towards an issue.

3.Sampling technique is the choice of a subset of people from among an immense masses to survey characteristics of the 50 respondents. The clear unpredictable procedure has been chosen for this assessment. [19]-[23]

4.Simple unpredictable testing system, acknowledge that each and every unit in the people has equal probability of occasion or comparable probability of occasion and the examining units are picked discretionarily. A reasonable subjective selection of individuals is basic to address the people. The pro has taken 50 models subjectively from the hard and fast masses. Basic wellsprings of data assembled through study in google structures and discretionary source from magazines, journals and site. [11]-[15]

5.Tools and Techniques Used For Analysis Tools used for the examination were ANOVA and chi-square using SPSS.

\section{RESULTS AND INTERPRETATION}

1. HYPOTHESIS 1:- H0- There is no significant relationship between income and the factors which influence to use cab apps.

2. H1- There is significant relationship between income and the factors which influence to use cab apps.

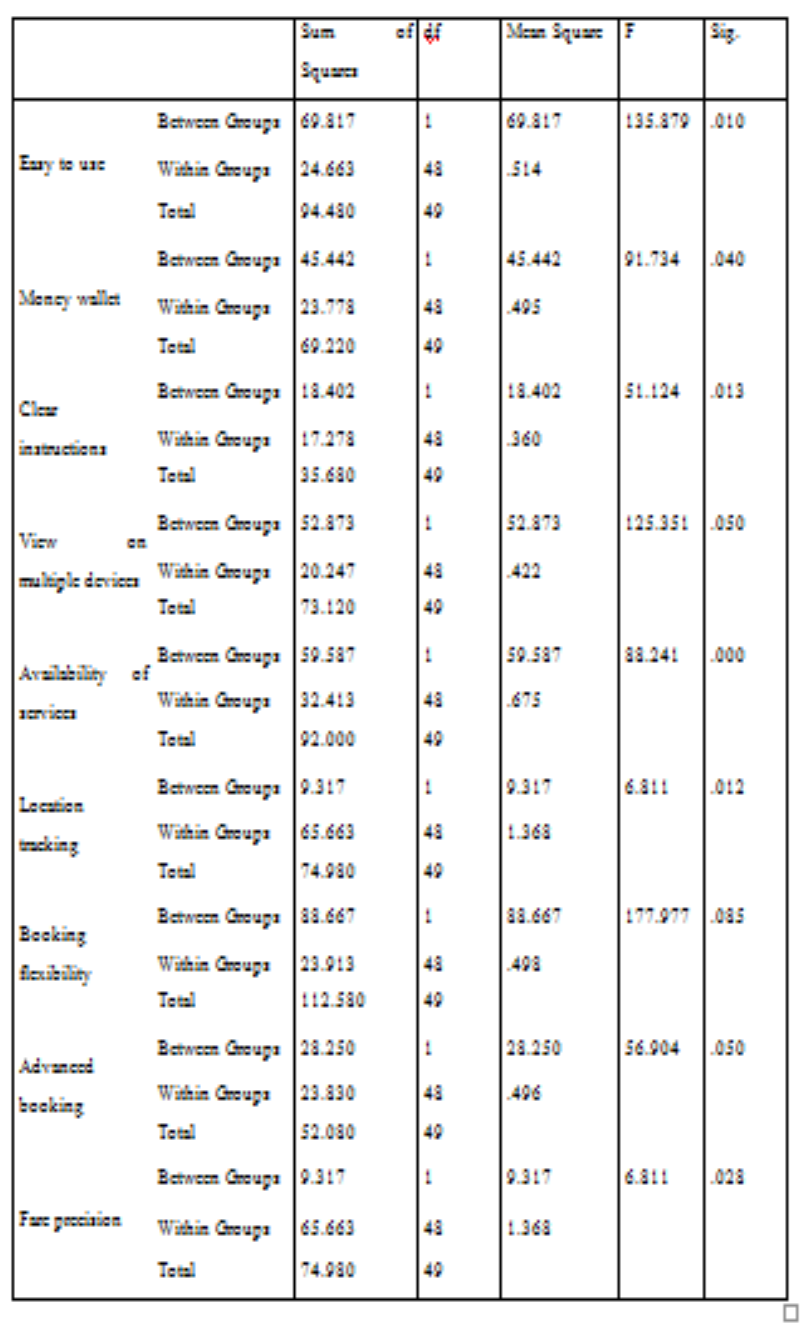

\section{FINDINGS}

From the study the following are the observed findings,

1. Out of 50 respondents, majority of the respondents fall under the age group 25-30

2. Majority of the respondents are female.

3. Out of 50 respondents, majority of the respondents fall under the income group of Rs.20000- Rs.30000.

4. Majority of the respondents prefer ola cab only.

5 . The majority of the respondents are influenced by advanced booking and view on multiple devices.

6 . The majority of the respondents are attracted towards the benefits like payment via app and ratings on the app.[23]-[25]

\section{CONCLUSION}

People are very conscious about the price and the timing. People prefer cabs because of the reliability and for the sake of convenience. The pricing strategies used by the organized cab operators are also a worth preferring to different cabs. The study compile only with the factors and the customers impact. But the major problems and the pricing strategies of the cab operators can also be studied in a wide manner. 


\section{REFERENCES}

1. Vasanthi, S. \& Rabiyathul Basariya, S. 2019, "Influence of value analysis and cross training in industry", International Journal of Engineering and Advanced Technology, vol. 8, no. 6, pp. 1810-1811.

2. Velvizhi, R., Sri Gowtham, S. \& Jeya Priya, D. 2019, "Examination of early feedbacks for effective product retailing on E-commerce websites", International Journal of Engineering and Advanced Technology, vol. 8, no. 6 Special Issue 2, pp. 703-706.

3. Anuradha, C., Pothumani, S. \& Kavitha, R. 2019, "A novel method towards E-commerce", International Journal of Engineering and Advanced Technology, vol. 8, no. 6 Special Issue 2, pp. 535-538.

4. Thomas, J. \& Rabiyathul Basariya, S. 2019, "A study on the issues of financial ratio analysis", Indian Journal of Public Health Research and Development, vol. 10, no. 3, pp. 1079-1081.

5. Ramachandran, S. \& Rabiyathul Basariya, S. 2019, "Online marketing - study on customer satisfaction and relationship", Indian Journal of Public Health Research and Development, vol. 10, no. 3, pp. 1072-1078.

6. Priya, R., Vinothini, G. \& Cor Jesu, C.D. 2019, "The mentor-protégé relationship for professional growth", Journal of Advanced Research in Dynamical and Control Systems, vol. 11, no. 9 Special Issue, pp. 1110-1119.

7. Jannifer Rani, N., Bina Pani, S. \& Nimisha, N.S. 2019, "A study on money back polices available in LIC", Journal of Advanced Research in Dynamical and Control Systems, vol. 11, no. 9 Special Issue, pp. 833-839.

8. Saillaja, V., Jhansi Rani, K. \& Catherine, R. 2019, "Global marketing management planning and organization", Journal of Advanced Research in Dynamical and Control Systems, vol. 11, no. 9 Special Issue, pp. 489-493

9. Saillaja, V., Jhansi Rani, K. \& Catherine, R. 2019, "The new phase of marketing information system", Journal of Advanced Research in Dynamical and Control Systems, vol. 11, no. 9 Special Issue, pp. 482-488.

10. Thoufiqulla \& Raju, D.V. 2019, "Perception of indian investor towards investment in mutual funds with special reference to mip funds", Journal of Advanced Research in Dynamical and Control Systems, vol. 11, no. 5, pp. 177-183.

11. Jasmine, K.R.M. \& Basariya, S.R. 2018, "A study on the customers benefits on mutual funds", International Journal of Civil Engineering and Technology, vol. 9, no. 4, pp. 45-48.

12. Vasanthi, S. \& Basariya, S.R. 2019, "Pros and cons of on the job training versus off the job training", International Journal of Scientific and Technology Research, vol. 8, no. 10, pp. 671-674.

13. Pavithra, J. \& Ganesan, M. 2016, "A study on awareness and impact of micro-financial schemes", International Journal of Applied Business and Economic Research, vol. 14, no. 8, pp. 5449-5460.

14. Pavithra, J., Dilli Babu, P. \& Ambuli, T.V. 2014, "A study on budgetary control at Maruti Service Masters, Chennai", International Journal of Applied Business and Economic Research, vol. 12, no. 2, pp. 151-161.

15. Gunaraja, T.M. \& Venkatrama Raju, D. 2018, "Determining factors of organisational climate with reference to leadership styles", International Journal of Mechanical Engineering and Technology, vol. 9, no. 9, pp. 1327-1332.

16. Gunaraja, T.M. \& Venkatrama Raju, D. 2018, "The role of job satisfaction and training of employees in determining organisational climate of a selected industry", International Journal of Civil Engineering and Technology, vol. 9, no. 8, pp. 1266-1269.

17. Aarathy, T.S. \& Raju, D.V. 2018, "Performance appraisal and its effects on employees with respect to it sector in Chennai city", International Journal of Civil Engineering and Technology, vol. 9, no. 6, pp. 1535-1538.

18. Aarathy, T.S. \& Raju, D.V. 2018, "Employee perception towards performance appraisal system in IT sector", International Journal of Mechanical Engineering and Technology, vol. 9, no. 5, pp. 131-135.

19. Porselvi, W., Jublee, D. \& Sivanesan, G. 2018, "A study on factors influencing adoption of technology and innovation in banking industry, tamilnadu, India", International Journal of Mechanical Engineering and Technology, vol. 9, no. 5, pp. 789-800.

20. Akessa, G.M. and Dhufera, A.G., 2015. Factors That Influences Students Academic Performance: A Case of Rift Valley University, Jimma, Ethiopia. Journal of Education and Practice, 6(22), pp.55-63.
21. Miller, G. and Shih, C.C., 1999. A faculty assessment of the academic rigor of on-and off-campus courses in agriculture. Journal of Agricultural Education, 40, pp.57-65.

22. Tsinidou, M., Gerogiannis, V. and Fitsilis, P., 2010. Evaluation of the factors that determine quality in higher education: an empirical study. Quality Assurance in education, 18(3), pp.227-244.

23. Farooq, M.S., Chaudhry, A.H., Shafiq, M. and Berhanu, G., 2011 Factors affecting students' quality of academic performance: a case of secondary school level. Journal of quality and technology management, 7(2), pp.1-14.

24. Fitsilis, P., Gerogiannis, V. and Anthopoulos, L., 2014. Ontologies for software project management: a review. Journal of Software Engineering and Applications, 7(13), p.1096.

25. Adams, J.D. and Jaffe, A.B., 1996. Bounding the effects of R\&D: an investigation using matched establishment-firm data(No. w5544). National bureau of economic research.

\section{AUTHORS PROFILE}

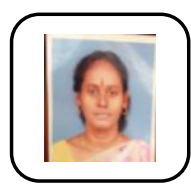

Sumathy Arjunan, Assistant Professor, Department of Science \& Humanities,Bharath Institution Of Higher Education And Research TamilNadu,India

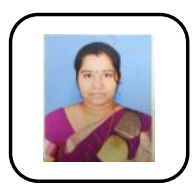

S. Barani Chelvi, Assistant Professor, Department of Science \& Humanities,Bharath Institution Of Higher Education And Research TamilNadu,India

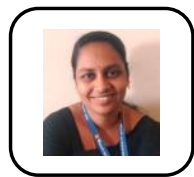

Venkata Srilatha Assistant Professor, Department Department of Science \& Humanities, Bharath Institution Of Higher Education And Research TamilNadu,India 